\title{
Intrapelvic acetabulum surgery: does the positioning of the plate fixation play a role in the stability of the osteosynthesis?
}

\author{
Intrapelvik asetabulum cerrahisi: Plak tespitinin pozisyonlandırılması \\ osteosentezin stabilitesinde bir rol oynar mı?
}

\author{
Gergely Sztrinkai, MD., ${ }^{1}$ Tamás Bodzay, MD, PhD., ${ }^{1}$ Benjámin Madarász, MD., ${ }^{2}$ \\ Gergely Zoltán, MD., ${ }^{1}$ Tamás Gál, MD., ${ }^{3}$ Károly Váradi, PhD. D.Sc. ${ }^{2}$ \\ 'Trauma Centre, Péterfy Hospital, Budapest, Hungary \\ ${ }^{2}$ Faculty of Mechanical Engineering, Institute of Machine Design University of Technology and Economics, Budapest, Hungary \\ ${ }^{3}$ Semmelweis University, Trauma Department, Budapest, Hungary
}

\begin{abstract}
Objectives: This study aims to investigate whether positioning of the plate fixation plays a role in the stability of the osteosynthesis.

Materials and methods: We used finite element modelling to model an anterior pillar fracture and a T-type fracture of the acetabulum. Fracture fixation was carried out in three different variations: cranially positioned plate, medially positioned plate, and a combination of the two methods. In all cases, 3-3 screws were inserted on both ends of the plate to fix the fracture.
\end{abstract}

Results: In both fractures, nearly the same amount of displacement was detected in the fracture gap using a cranially positioned or medially positioned plate, and the amount of displacement was not less when using both plates simultaneously.

Conclusion: The position of the plate fixation does not affect the stability of the osteosynthesis and in cases of simple fracture patterns, fixation using two plates does not provide more stability than one plate alone.

Keywords: Finite element analysis; fracture fixation; pelvis.

The approaches used in the surgical treatment of acetabulum fractures over the past 50 years since the work of Judet et al. ${ }^{[1]}$ have not changed significantly. We use the Kocher-Langenbeck approach to reach the posterior wall, the posterior pillar, or in certain cases of transverse fractures, whereas anterior or dual approaches are used in all other fracture patterns. ${ }^{[1]}$ The gold standard of anterior approaches

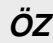

Amaç: Bu çalışmada plak tespitinin pozisyonlandırılmasının osteosentezin stabilitesinde bir rol oynayıp oynamadığ araştırıldı.

Gereç ve yöntemler: Asetabulumun anterior kolon kırığ ve T-tipi kırı̆̆ının örneklendirilmesi için sonlu elemanlar modeli kullanıldı. Kırık tespiti üç farklı varyasyonda gerçekleştirildi: kraniyal pozisyonlu plak, medial pozisyonlu plak ve iki yöntemin bir kombinasyonu. Kırığ tespit etmek için tüm olgularda plağın iki ucuna 3-3 vidalar yerleştirildi.

Bulgular: Her iki kırıkta kraniyal pozisyonlu veya medial pozisyonlu plak kullanıldığında kırık aralığında neredeyse aynı miktarda kayma saptandı ve iki plak eşzamanlı kullanıldığında kayma miktarı daha az değildi.

Sonuç: Plak tespitinin pozisyonu osteosentezin stabilitesini etkilememekte ve basit kırık paternlerinde iki plak kullanılan tespit tek bir plaktan daha fazla stabilite sağlamamaktadır.

Anahtar sözcükler: Sonlu elemanlar analizi; kırık tespiti; pelvis.

is the Judet-Letournel ilioinguinal approach. With this approach, one can visualize the anterior pillar and the pelvic brim. Following reduction of the fracture, a cranially positioned plate fixation is applied. The modified Stoppa approach, reported by Hirvensalo ${ }^{[2]}$ in 1993, substantially reduced the invasiveness of the operation. In addition, with this "intrapelvic" acetabulum approach, the quadrilateral

- Received: September 09, 2015 Accepted: October 07, 2015

- Correspondence: Gergely Sztrinkai, MD. Trauma Centre, Péterfy Hospital, Fiumei str. 17, H-1081, Budapest, Hungary

Tel: +36 709323087 Fax: +3613338973 e-mail: sztrinkaig@gmail.com 
surface can be actually visualized, while it could only be palpated with the Judet-Letournel approach. Another advantage of this operation is that a medially positioned plate can be applied to the pelvic brim and quadrilateral surface. However, a disadvantage of this approach is the difficulty involved in positioning a plate onto the cranial side. In 2009, Keel et al ${ }^{[3]}$ introduced into clinical practice the pararectus approach for acetabulum surgeries and reported his results in 2012. It combines the advantages of both the Judet-Letournel and modified Stoppa approaches: less invasively, the quadrilateral surface is exposed, and a medially as well as a cranially positioned plate can be applied. Since this approach became part of our routine practice, we felt the requirement to examine which position of the plate fixation provides greater stability, is a plate synthesis necessary for fixation of the acetabulum fracture, and if so, when do we choose to use a cranially positioned plate, a medially positioned plate, or both plates? Therefore, in this study, we aimed to investigate whether positioning of the plate fixation plays a role in the stability of the osteosynthesis.

\section{MATERIALS AND METHODS}

In our previous studies conducted in Trauma Center (Péterfy Hospital, Budapest) and the University of Technology and Economics (Budapest) in 2014, we created a more realistic anatomic model by three dimension (3D) scanning a plastic pelvis model. ${ }^{[4]}$ We modelled an anterior pillar fracture and a T-type fracture on the acetabulum, in which case the pattern of the fracture line ran vertically through the acetabulum and reached the linea terminalis and ran through the obturator foramen as well. Thus it is possible to perform fixation of a T-type fracture with the use of a medially positioned plate alone (Figure 1).

Fracture fixation was carried out in three different variations: cranially positioned plate, medially positioned plate, and a combination of the two

(a)
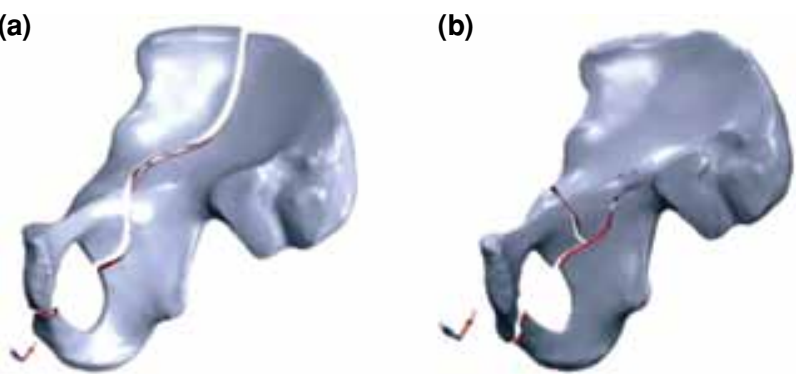

Figure 1. (a) Model of an anterior pillar fracture and (b) T-type fracture. methods. In all cases, 3-3 screws were inserted on both ends of the plate to fix the fracture.

We used a half-pelvis geometric model because of its simplicity and faster mesh generation. The values of tension and displacement in the half-pelvis model were almost the same as in the whole pelvis model. The plate-bone contact and acetabulum fixation was bonded, the fracture gap was $0.1 \mathrm{~mm}$, and contact was frictionless.

We further developed the plastic material model in the following manner: first, we established a so-called hybrid model consisting of a cortical layer built of shell elements and a cancellous component made of body elements. This is a more realistic material model compared to the previous one, but it was more difficult to model the transition between the cortical and cancellous layers. In addition, the program was incapable of starting the simulation; therefore, this model was not used. For these reasons, we developed a so-called hollow model, in which we removed the cancellous bone elements (Figure 2). Thus we neglected the effects of the cancellous bone layer, as other authors did previously. ${ }^{[5]}$ The thickness of the cortical layer was based on measurements of human pelvic computed tomography (CT) scans, which were derived from 64 slices of the ileum and 46 slices of the sacrum.

As in the previous examinations, the mechanical properties were chosen according to data of Abé et al. ${ }^{[6]}$ The elastic modulus of the cortical layer was $17,000 \mathrm{MPa}$, and Poisson's ratio was 0.3. The validation of the model was performed on cadaver experiments, as mentioned in our previous publications, ${ }^{[7]}$ concerning the operative fixation of Denis type I

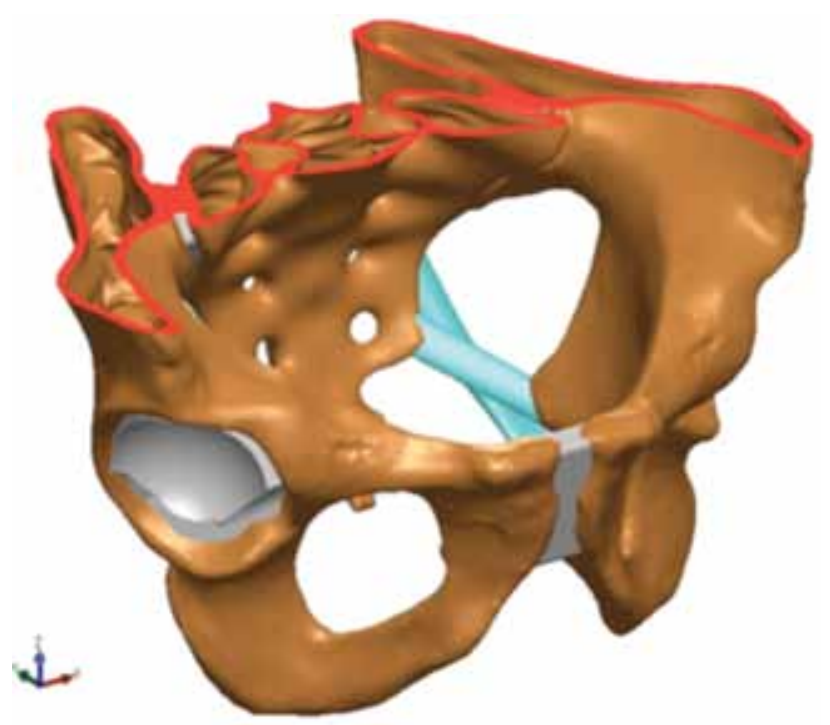

Figure 2. Hollow pelvis model, cancellous bone is "neglected". 

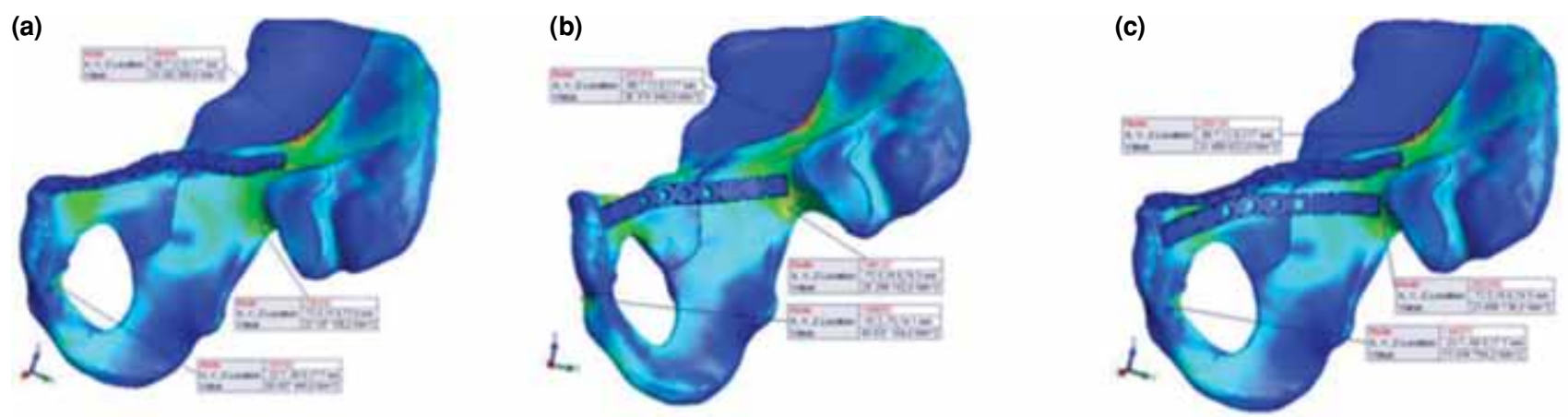

Figure 3. Tension distribution in an anterior pillar fracture; (a) cranially positioned plate, (b) medially positioned plate, (c) cranial and medial plate fixation.

sacrum fracture and symphysiolysis. ${ }^{[8,9]}$ Load and boundary parameters of each case are as follows.

Case 1- Anterior pillar fracture, weight bearing on one lower extremity: load on the promontorium, in the Z-axis, $500 \mathrm{~N}$, node-to node contact at the fracture site, bonded contact in the hip joint; cranially positioned plate fixation.

Case 2- Anterior pillar fracture, weight bearing on one lower extremity: load on the promontorium, in the Z-axis, $500 \mathrm{~N}$, node-to node contact at the fracture site, bonded contact in the hip joint; medially positioned plate fixation.

Case 3- Anterior pillar fracture, weight bearing on one lower extremity: load on the promontorium, in the Z-axis, $500 \mathrm{~N}$, node-to node contact at the fracture site, bonded contact in the hip joint; cranially and medially positioned plate fixation.

Case 4- T-type fracture, weight bearing on one lower extremity: load on the promontorium, in the Z-axis, $500 \mathrm{~N}$, node-to node contact at the fracture site, bonded contact in the hip joint; cranially positioned plate fixation.
Case 5- T-type fracture, weight bearing on one lower extremity: load on the promontorium, in the Z-axis, $500 \mathrm{~N}$, node-to node contact at the fracture site, bonded contact in the hip joint; medially positioned plate fixation.

Case 6- T-type fracture, weight bearing on one lower extremity: load on the promontorium, in the Z-axis, $500 \mathrm{~N}$, node-to node contact at the fracture site, bonded contact in the hip joint; cranially and medially positioned plate fixation.

SolidWorks 2012 3D program was used for the finite element analysis. The finite element mesh was comprised of about 123,000 secondary Tetra elements.

\section{RESULTS}

Case 1- Anterior pillar fracture, weight bearing on one lower extremity, cranially positioned plate fixation: Maximum tension in the bones was $70 \mathrm{MPa}$, in the metals was $15 \mathrm{MPa}$; displacement in the fracture gap was $0.16 \mathrm{~mm}$ (Figure 3a).

Case 2- Anterior pillar fracture, weight bearing on one lower extremity, medially positioned plate fixation: Maximum tension in the bones was $40 \mathrm{MPa}$, (a)

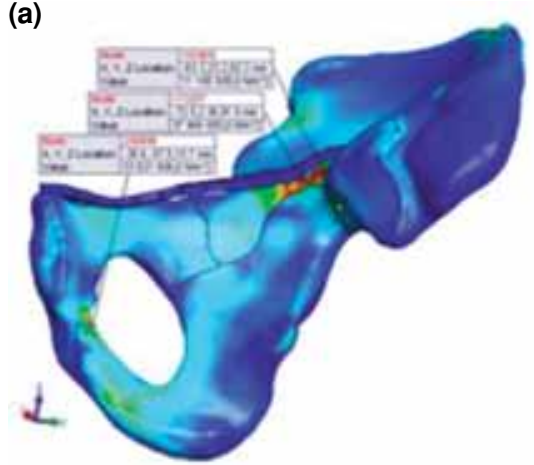

(b)

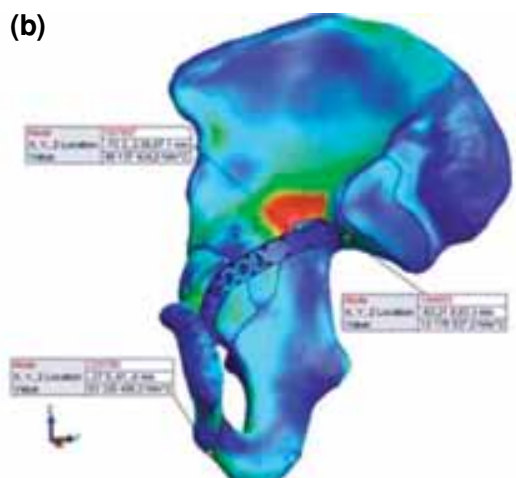

(c)

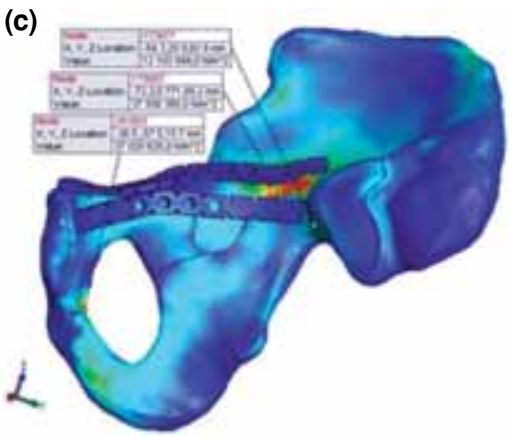

Figure 4. Tension distribution in a T-type fracture; (a) cranially positioned plate, (b) medially positioned plate, (c) cranial and medial plate fixation. 
in the metals was $14 \mathrm{MPa}$; displacement in the fracture gap was $0.15 \mathrm{~mm}$ (Figure $3 \mathrm{~b}$ ).

Case 3-Anterior pillar fracture, weight bearing on one lower extremity, cranially and medially positioned plate fixation: Maximum tension in the bones was $73 \mathrm{MPa}$, in the metals was $15 \mathrm{MPa}$; displacement in the fracture gap was $0.16 \mathrm{~mm}$ (Figure 3c).

Case 4- T-type fracture, weight bearing on one lower extremity, cranially positioned plate fixation: Maximum tension in the bones was $34 \mathrm{MPa}$, in the metals was $32 \mathrm{MPa}$; displacement in the fracture gap was $0.18 \mathrm{~mm}$ (Figure $4 \mathrm{a}$ ).

Case 5- T-type fracture, weight bearing on one lower extremity, medially positioned plate fixation: Maximum tension in the bones was $83 \mathrm{MPa}$, in the metals was $45 \mathrm{MPa}$; displacement in the fracture gap was $0.16 \mathrm{~mm}$ (Figure $4 \mathrm{~b}$ ).

Case 6- T-type fracture, weight bearing on one lower extremity, cranially and medially positioned plate fixation: Maximum tension in the bones was $37 \mathrm{MPa}$, in the metals was $29 \mathrm{MPa}$; displacement in the fracture gap was $0.18 \mathrm{~mm}$ (Figure 4c).

\section{DISCUSSION}

The osteosynthesis of fractures of the acetabulum is a demanding challenge in the care of the injured patients. Indications for surgery include an unstable joint, articular surface incongruence greater than $1 \mathrm{~mm}$, fracture gap displacement greater than $2 \mathrm{~mm}$, or if the "roof arc angle" is less than 45 degrees on at least one of the anteroposterior-ala-obturator views on the radiographs. The modified Stoppa approach mends the disadvantages of the JudetLetournel approach. ${ }^{[2]}$ The operation is significantly less invasive and the quadrilateral surface is better accessed. The medial positioning of the plate fixation is easier, while the positioning of the screws for a plate applied on the cranial side is more difficult. The prevailing pararectus approach, ${ }^{[3]}$ which emerged in the past five years, combines the advantages of both
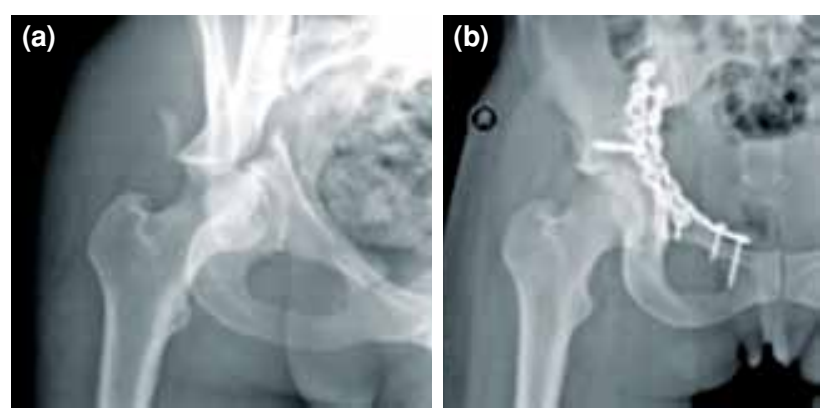

Figure 5. (a) Transverse fracture, (b) fixed with two plates. the Judet-Letournel and Stoppa approaches. It is less invasive, the quadrilateral surface is exposed, and the external iliac artery and vein are handled safely, since they are mobilized and secured. As a consequence, a plate can be positioned cranially by access through a window lateral to the vessels, or a plate can be positioned medially through a window medial of the vessels. The questions arise whether it is necessary to apply two plate fixations, or we only use one plate, and whether that plate should be positioned medially or cranially. These were the questions we addressed using a finite element acetabulum model..$^{[10,11]}$ We further developed an anatomically realistic, plastic pelvis model, which we had used in our previous research ${ }^{[4]}$ After scanning the plastic model, we used CT images to model the different thicknesses of the cortical layers of the bone, but we neglected the role of the cancellous layer, as other authors also did. ${ }^{[5]}$ We used a half-pelvis, more precisely, an ilium bone model. We modelled an anterior pillar fracture and a T-type fracture. In both cases, the fracture patterns were chosen in a way that allowed for the application of a cranially as well as a medially positioned plate fixation. In each fracture type and in each plate fixation, 3-3 screws were modelled (3 screws on each side of the fracture). A "bonded" connection between the plate and screws corresponds to the plate-screw contact in locked plating techniques used nowadays. We did not take into account friction in the fracture gap; we modelled smooth fracture surfaces and the measurements were performed with the injured joint being supported from underneath. The measurements were performed under these provocative, unrealistic circumstances - in which the patient is bearing weight on the ipsilateral extremity of the injured side. In this manner, we tried to gain results with extreme amount of loading. The degree of displacement and tension measured on the model demonstrate that there is no significant difference in the amount of displacement of the fracture gap whether the plate fixation was positioned cranially or medially to stabilize the fracture. In fact, the displacement values were not lower when both cranial and medial plates were used simultaneously. We do not expect screw fractures or implant failures based on the tension values detected in the bones and implants. This conclusion is also true for anterior pillar fractures and T-type fractures as well. Any surgical approach and position of the plate fixation according to the preference of the operating surgeon are expected provide enough stability, as long as the reduction was properly performed. However, the use of dual plating for these more simple fracture patterns is probably not necessary (Figure 5). 


\section{Declaration of conflicting interests}

The authors declared no conflicts of interest with respect to the authorship and/or publication of this article.

\section{Funding}

The authors received no financial support for the research and/or authorship of this article.

\section{REFERENCES}

1. Judet R, Judet J, Letournel E. Fractures of the acetabulum: classification and surgical approaches for open reduction. Preliminary report. J Bone Joint Surg [Am] 1964;46:1615-46.

2. Hirvensalo E, Lindahl J, Böstman O. A new approach to the internal fixation of unstable pelvic fractures. Clin Orthop Relat Res 1993;297:28-32.

3. Keel MJ, Ecker TM, Cullmann JL, Bergmann M, Bonel HM, Büchler L, et al. The Pararectus approach for anterior intrapelvic management of acetabular fractures: an anatomical study and clinical evaluation. J Bone Joint Surg [Br] 2012;94:405-11.

4. Bodzay T, Sztrinkai G, Pajor S, Gál T, Jónás Z, Erdös P, et al. Does surgically fixation of pubic fracture increase the stability of the operated posterior pelvis? Eklem Hastalik Cerrahisi 2014;25:91-5.

5. Anderson AE, Peters CL, Tuttle BD, Weiss JA. Subject-specific finite element model of the pelvis: development, validation and sensitivity studies. J Biomech Eng 2005;127:364-73.

6. Abé H, Hayashi K, Sato M, editors. Data book on mechanical properties of living cells, tissues, and organs. New York: Springer Verlag; 1996.

7. Bodzay T, Szita J, Manó S, Kiss L, Jónás Z, Frenyó S, et al. Biomechanical comparison of two stabilization techniques for unstable sacral fractures. J Orthop Sci 2012;17:574-9.

8. Szita J. Treatment of pelvic injuries. In: Cziffer E, editor. Operatíve Treatment of the Fractures (in Hungarian). Budapest: Springer Hungarica; 1997. p. 417-25.

9. Ragnarsson B, Olerud C, Olerud S. Anterior square-plate fixation of sacroiliac disruption. 2-8 years follow-up of 23 consecutive cases. Acta Orthop Scand 1993;64:138-42.

10. Shim VB, Böshme J, Vaitl P, Josten C, Anderson IA. An efficient and accurate prediction of the stability of percutaneous fixation of acetabular fractures with finite element simulation. J Biomech Eng 2011;133:094501.

11. Yildirim A, Alemdaroglu $\mathrm{K}$, Yüksel H, Öken Ö, Ucaner A. Finite element analysis of the stability of transverse acetabular fractures in standing and sitting positions by different fixation options. Injury 2013;44:S8-S9. 